\title{
PENGARUH WAKTU EKSTRAKSI DENGAN METODE ULTRASONIK TERHADAP KANDUNGAN VITAMIN C,PROTEIN, DAN FITOKIMIA EKSTRAK RAMBUT JAGUNG (Zea mays L.)
}

\author{
The Effect of Time of Extraction with Ultrasonic Methods on the Content of \\ Vitamin C, Protein and Phytochemicals of Corn Hair Extract (Zea Mays L.)
}

\author{
Muhammad Edi Setyantoro ${ }^{1}$ Haslina $^{2}$, Sri Budi Wahjuningsih ${ }^{3}$ \\ ${ }^{1}$ Mahasiswa Teknologi Hasil Pertanian Universitas Semarang, \\ ${ }^{2,3}$ Staff Pengajar Teknologi Hasil Pertanian Universitas Semarang \\ Jl. Soekarno-Hatta Tlogosari Semarang, 50196 \\ edisetyantoro14@gmail.com
}

\begin{abstract}
ABSTRAK
Rambut jagung yang dikenal sebagai limbah pangan kini mulai banyak diteliti karena kandungan antioksidan yang tinggi. Rambut jagung memiliki kandungan berupa alkaloid, steroid, sitosterol dan stigmasterol, tanin, flavonoid, protein, karbohidrat, vitamin, minyak atsiri, dan garam mineral seperti: $\mathrm{Na}, \mathrm{K}, \mathrm{Mg}, \mathrm{Ca}$.

Tujuan dari penelitian ini adalah untuk mengetahui pengaruh penggunaan metode ultrasonik terhadap kandungan fitokimia, vitamin c, dan protein dalam pengekstrakan rambut jagung dengan berbagai waktu ekstraksi.

Penelitian ini menggunakan metode ultrasonik dengan pelarut methanol $70 \%$. Rancangan percobaan yang digunakan dalam penelitian ini adalah Rancangan Acak Kelompok (RAK) dengan berbagai macam waktu ekstraksi. Dengan 5 perlakuan dan diulang sebanyak 4 kali, dimana setiap perlakuan dengan konsentrasi ekstrak (bahan:pelarut) 1:10, : $\mathrm{P} 1: 60^{\circ} \mathrm{C}$ selama 20 menit, $\mathrm{P} 2: 60^{\circ} \mathrm{C}$ selama 30 menit, $\mathrm{P} 3: 60^{\circ} \mathrm{C}$ selama 40 menit, $\mathrm{P} 4: 60^{\circ} \mathrm{C}$ selama 50 menit, dan $\mathrm{P} 5: 60^{\circ} \mathrm{C}$ selama 60 menit. Data yang diperoleh dianalisa dengan menggunakan ANOVA dan apabila ada perbedaan yang nyata maka akan dilanjut dengan menggunakan uji DMRT taraf 5\%. Adapun variable yang diamati yaitu uji aktivitas antioksidan, uji kandungan flavonoid, uji total fenol, vitamin $\mathrm{C}$, dan protein.

Hasil penelitian menunjukkan bahwa berbagai macam waktu menggunakan metode ultrasonik terhadap ekstrak rambut jagung berpengaruh nyata $(\mathrm{p}<0,05)$ terhadap uji aktivitas antioksidan, uji kandungan flavonoid, uji total fenolik, kadar vitamin C, dan kadar protein. Dengan hasil terbaik adalah pada waktu 60 menit terhadap fitokimia memberi hasil uji aktivitas antioksidan sebesar 70,55\%, uji kandungan flavonoid sebesar 2,45 mg.QE/g dan uji total fenol sebesar 1,78 mg.GAE/g, vitamin c sebesar 53,98 Mg100/ml, dan kadar protein sebesar 0,58\%.
\end{abstract}

Kata Kunci : Rambut Jagung, Ekstraksi Ultrasonik, Waktu 


\begin{abstract}
Corn silk which is known as food waste is now widely studied because of its high antioxidant content. Corn silk contains alkaloids, steroids, sitosterol and stigmasterol, tannins, flavonoids, proteins, carbohydrates, vitamins, essential oils, and mineral salts such as: $\mathrm{Na}, \mathrm{K}, \mathrm{Mg}$, $\mathrm{Ca}$.

The purpose of this study was to determine the effect of the use of ultrasonic methods on phytochemical, vitamin $\mathrm{C}$, and protein content in extracting corn silk with various extraction times.

This study uses an ultrasonic method with $70 \%$ methanol solvent. The experimental design used in this study was a Randomized Block Design (RBD) with a variety of extraction times. With 5 treatments and repeated 4 times, where each treatment with a concentration of extract (material: solvent) 1:10,: P1: $60 \mathrm{oC}$ for 20 minutes, $\mathrm{P} 2: 60^{\circ} \mathrm{C}$ for 30 minutes, $\mathrm{P} 3: 60^{\circ} \mathrm{C}$ for 40 minutes, $\mathrm{P} 4: 60^{\circ} \mathrm{C}$ for 50 minutes, and P5: $60^{\circ} \mathrm{C}$ for 60 minutes. The data obtained were analyzed using ANOVA and if there were significant differences it would be continued using the DMRT test of 5\% level. The observed variables are antioxidant activity test, flavonoid content test, total phenol test, vitamin $\mathrm{C}$ test, and protein test.

The results showed that various times using the ultrasonic method on corn silk extract significantly affected $(\mathrm{p}<0.05)$ the antioxidant activity test, flavonoid content test, total phenolic test, vitamin $\mathrm{C}$ content, and protein content. With the best results, phytochemicals gave $60.55 \%$ of the antioxidant activity test, a flavonoid content test of $2.45 \mathrm{mg} . \mathrm{QE} / \mathrm{g}$ and a total phenol test of $1.78 \mathrm{mg}$.GAE / g, vitamin c of $53.98 \mathrm{Mg} 100$ / $\mathrm{ml}$, and protein content of $0.58 \%$.
\end{abstract}

\title{
Keywords: Corn Silk, Ultrasonic extraction, Time
}

\section{PENDAHULUAN}

Seperti yang sudah diketahui bersama bahwa pada jagung terdapat rambut jagung (corn silk) yang hingga saat ini pemanfaatannya masih sangat minim. Rambut jagung merupakan sebutan yang mudah untuk menggantikan pengertian dari putik bunga dari jagung. Warna dari rambut jagung biasanya dimulai dengan warna hijau yang kemudian berubah menjadi kemerahan, kuning dan cokelat muda. Panjang dari rambut jagung bisa mencapai $30 \mathrm{~cm}$ atau lebih dengan rasa sedikit manis (Hasanudin et al., 2012).

Ekstraksi merupakan suatu proses penarikan komponen senyawa yang di inginkan dari suatu bahan dengan cara pemisahan satu atau lebih komponen dari suatu bahan yang merupakan sumber komponennya. Pada umumnya ekstraksi akan semakin baik bila permukaan serbuk simplisia yang bersentuhan dengan pelarut semakin luas. Dengan demikian, semakin halus serbuk simplisia maka akan semakin baik ekstraksinya.

Ekstraksi ultrasonik adalah modifikasi dari metode maserasi. Ekstrak diproses menggunakan ultrasound (gelomang ultrasonik) berfrekuensi, dengan getaran yang tinggi, yaitu $20 \mathrm{kHz}$. Prinsip kerja ini yaitu dengan mengamati sifat akustik gelombang ultrasonik yang dirambatkan melalui medium yang dilewati. Saat gelombang merambat, medium yang dilewati akan mengalami getaran. Medium perambatan dengan cairan dikenal dengan nama ekstraksi ultrasonic bath. Getaran akan memberikan pengadukan intensif terhadap proses ekstraksi. Pengeadukan akan meningkatkan osmosis antara bahan dengan pelarut sehingga akan meningkatkan proses ekstraksi. 
Metode ekstraksi ultrasonik juga dikenal dengan sonokimia, yaitu pemanfaatan efek gelombang ulgrasonik untuk mempengaruhi perubahan-perubahanyang terjadi pada proses kimia. Keuntungan utama ekstraksi gelombang ultrasonik antara lain efisiensi lebih besar, waktu operasi lebih singkat dan biasanya laju perpindahan masa lebih cepat jika dibandingkan dengan ekstraksi

\section{Tempat Penelitian}

\section{METODE PENELITIAN}

Penelitian ini di Laboratorium Terpadu Universitas Diponegoro, Laboratorium Rekayasa Pangan dan Laboratorium Kimia Fakultas Teknologi Pertanian Universitas Semarang.

\section{Waktu Penelitian}

\section{Bahan}

Penelitian ini berlangsung selama bulan Juli 2019.

Bahan baku yang digunakan dalam penelitian ini adalah rambut jagung varietas pertiwi yang berasal dari perkebunan rakyat Kabupaten Blora, bahan untuk analisa, yaitu Metanol 70\%, Aquades, Kertas saring halus, Kain mori, dan Alumunium foil.

\section{Alat}

Alat yang digunakan dalam pembuatan serbuk rambut jagung meliputi loyang, ayakan 60 mesh, blender kering, termometer, sendok, baskom, dan plastik.

Alat untuk menguji parameter diantaranya neraca analitik (Denver Instrument M-310), alat ekstraksi ultrasonik bath (Elmer), beaker glass (Pyrex), corong kaca (Pyrex), gelas ukur (Pyrex), spatula, vacuum rotary evaporator (Buchi B-490), botol sampel, pipet tetes dan freezer (Gea AB-396 T-X). glassware (Pyrex), desikator, tabung reaksi (Pyrex), pipet volume (Pyrex), labu ukur (Pyrex), corong kaca (Pyrex), oven listrik (Memmert U.30), spektrofotometer dan kuvet (Unico UV-2100), Vortex mixer (LW Scientific), dan rak tabung reaksi.

\section{RANCANGAN PERCOBAAN}

Rancangan percobaan yang digunakan dalam penelitian ini adalah Rancangan Acak Kelompok (RAK). Dengan 5 perlakuan dan diulang sebanyak 4 kali, dimana setiap perlakuan dengan konsentrasi ekstrak (bahan:pelarut) 1:10. Perlakuan adalah sebagai berikut :

Waktu Ekstraksi:

$\mathrm{P} 1=20$ menit

$\mathrm{P} 2=30$ menit

$\mathrm{P} 3=40$ menit

$\mathrm{P} 4=50$ menit

P5 $=60$ menit 


\section{Prosedur Penelitian}

\section{PROSEDUR PENELITIAN}

Dalam penelitian ini ada lima parameter yang akan diamati yaitu uji fitokimia (aktivitas total fenol, flavonoid \& antioksidan), vitamin c, dan protein

Prosedur penelitian dapat dilihat pada diagram alir dibawah ini :

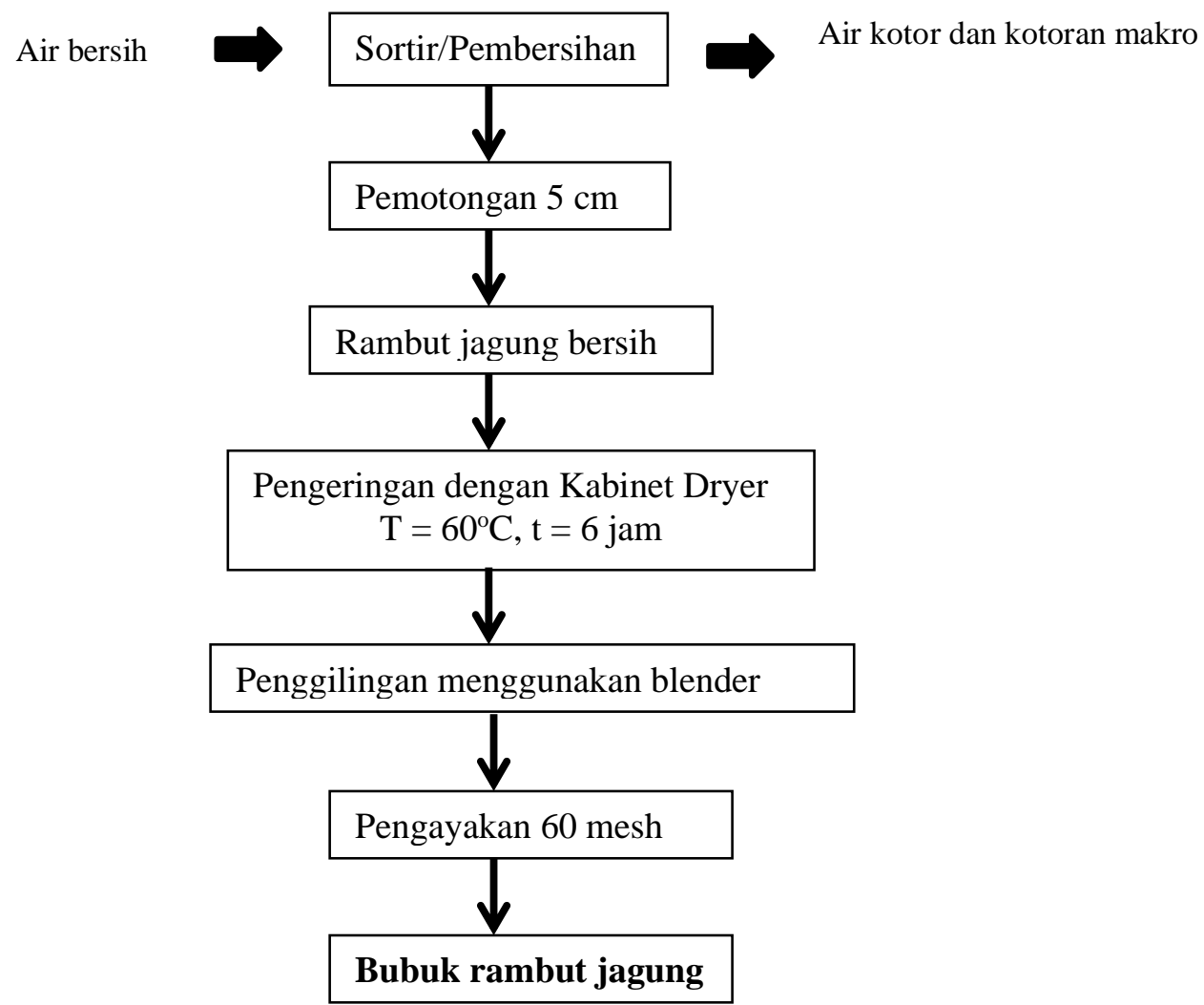

Gambar 1. Diagram pembuatan bubuk rambut jagung (A. Fuadi, 2012) yang telah termodifikasi 
Bubuk rambut jagung

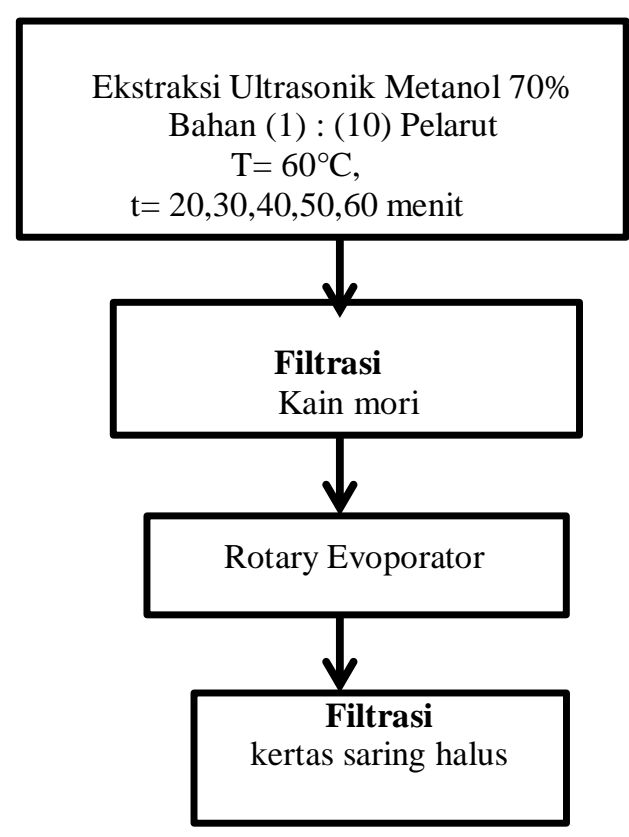

Ekstrak rambut jagung

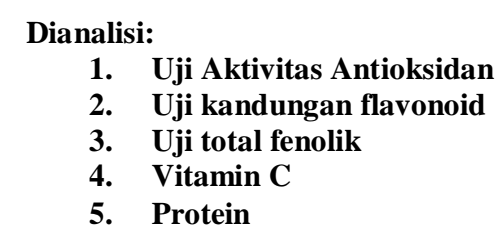

Gambar 2. Diagram ekstrak rambut jagung (A. Fuadi, 2012) yang telah termodifikasi

\section{Prosedur Analisis}

\section{Uji Kandungan Flavonoid (Nugroho et al., 2013)}

Metode yang digunakan mengacu pada metode Nugroho et al. (2013) dengan menggunakan pereaksi $\mathrm{AICI}_{3}$. Sebanyak $0,5 \mathrm{ml}$ ekstrak buah peredangan konsentrasi 1000 ppm dipipet ke dalam tabung reaksi, ditambahkan 1,5 ml etanol 0,1 $\mathrm{ml} \mathrm{AICI}_{3} 10 \%, 0,1 \mathrm{ml}$ $\mathrm{CH}_{3} \mathrm{COO} \mathrm{IM}$ dan 2,8 ml aqudest. Larutan dihomogenkan dan diinkubasi selama 30 menit. Absorbansi larutan di ukur dengan spektrofotometer UV-Vis pada panjang gelombang 415 nm. Pengukuran absorbansi dilakuakan 3 kali ulangan.

Kuersetin digunakan sebagai standar dengan seri konsentrasi 50 ppm, 100 ppm, 150 ppm dan 200 ppm. Kurva kalibrasi kuersetin digunakan untuk menentukan kadar senyawa total flavonoid yang tergandung dalam sampel melalui persamaan regresi dan dinyatakan dalam mg ekuivaken kuersetin ekstrak (mg QE/g ekstrak) dengan rumus perhitungan :

$$
\mathrm{C}=C 1 \times \frac{V}{M} x \mathrm{FP}
$$


Keterangan:

\begin{tabular}{ll}
\hline $\mathrm{C} \quad$ : Flavonoid (mg QE/g ekstrak) & $\mathrm{M}:$ Berat kstrak $(\mathrm{g})$ \\
$\mathrm{C} 1 \quad$ : Konsentrasi kuersetin $(\mathrm{mg} / \mathrm{I})$ & $\mathrm{FP}:$ Faktor pengenceran \\
$\mathrm{V}:$ Volume ekstrak (I) &
\end{tabular}

Uji Total Fenolik (Margaretta et al., 2011).

Pengujian total fenol dapat dilakukan dengan menggunakan teori FolinCiocalteau. Langkah pertama yang dilakukan adalam menyiapkan sampel sebanyak $2 \mathrm{mg}$ yang kemudian dilarutkan kedalam $1 \mathrm{~mL}$ metanol. Larutan dicampur dengan $5 \mathrm{~mL}$ reagen Folin-ciocalteau 1:10 (w/v) dengan pelarut akuades. Kemudian ditambahkan $4 \mathrm{~mL}$ larutan natrium karbonat 7,5\% (w/v) dengan pelarut akuades. Dibiarkan selama 30 menit pada suhu ruang dan kemudian diukur serapan pada panjang gelombang maksimal yaitu $765 \mathrm{~nm}$ dengan menggunakan spektrofotometer (Margaretta et al., 2011).

$$
\mathrm{C}=\frac{c V}{m}
$$

$$
\begin{aligned}
\mathrm{C} & =\text { konsentrasi total fenolik, mg GAE/g } \\
\mathrm{c} & =\text { konsentrasi gallic acid, } \mathrm{mg} \mathrm{GAE} / \mathrm{mL} \\
\mathrm{V} & =\text { volume larutan ekstrak rambut jagung dalam metanol } 10 \mathrm{~mL} \\
m & =\text { massa sampel ekstrak, gram }
\end{aligned}
$$

\section{Uji Aktivitas Antioksidan dengan Metode DPPH Sharma dan Bhat (2009)}

Berdasarkan Sharma dan Bhat (2009), sebanyak $1 \mathrm{ml}$ larutan sampel atau standar dimasukkan kedalam tabung reaksi, lalu penambahan $7 \mathrm{ml}$ methanol (sebagai blanko adalah $8 \mathrm{ml}$ methanol). Suspensi kemudian ditambahkan $2 \mathrm{ml}$ larutan DPPH $0,25 \mathrm{mM}$ (sehingga konsentrasi akhir DPPH dalam larutan menjadi $50 \mu \mathrm{M}$ ) yang kemudian di homogenkan dengan menggunakan vortex. Rangkaian kegiatan reaksi dilakukan pada ruang gelap. Inkubasi dilakukan selama 30 menit pada suhu ruang dan kemudian diukur absorbansinya pada panjang gelombang $517 \mathrm{~nm}$. Kapasitas dinyatakan dalam bentuk persentase penghambatan terhadap radikal DPPH dengan perhitungan :

$$
\begin{gathered}
\text { Kapasitas antioksidan }(\%)=\frac{(\text { A blanko }- \text { A sampel })}{\text { A blanko }} \times 100 \% \\
\text { Keterangan: } \quad \begin{array}{c}
\text { Ablanko }=\text { nilai absorbansi blanko, } \\
\text { Asampel }=\text { nilai absorbandi larutan sampel }
\end{array}
\end{gathered}
$$

\section{Kadar Vitamin C (AOAC,2005)}

Penetapan kadar Vitamin $\mathrm{C}$ dalam bahan pangan dapat dianalisa dengan berbagai metode, salah satunya dengan metode titrimetri. Penetapan dengan metode titrimetri sudah sesuai dengan metode prosedur analisis kimia yang didasarkan pada pengukuran jumlahlarutan titran yang digunakan untuk mentitrasi. Prinsip penetapan dengan metode titrimetri adalah asam askorbat dioksidasi oleh diklorofenol-indofenol menjadi senyawa dehidro askorbat. Akhir dari titrasi ditandai dengan terjadinya perubahan warna pada larutan sampai menjadi ungu.

\section{$\underline{\text { Tetesan iodin } \times 0,88 \times \mathrm{ml} \text { amilum }}$}

Vitamin $\mathrm{C}=\quad$ ml amilum $\quad \times 100 \%$




\section{Protein (AOAC,2005)}

Pengujian kadar protein dilakukan dengan menggunakan metode Kjeldahl, ada 3 tahap dalam menggunakan metode Kjeldahl yaitu : tahap destruksi, tahap destilasi dan tahap titrasi.

a. Tahap Destruksi

Di timbang $1 \mathrm{gr}$ sampel yang telah dihancurkan. Masukan sampel ke dalam Kjeldahl $100 \mathrm{ml}$, kemudian pipet $10 \mathrm{ml}$ asam sulfat pekat masukkan kedalam labu Kjeldahl. Ditambahkan katalisator untuk mempercepat destruksi. Labu Kjeldahl dipanaskan dengan menggunakan api kecil dan lama - kelamaan api dibesarkan hinga suhu menaik. Destruksi dihentikan apabila didapatkan larutan berwarna jernih kehijauan.

b. Tahap Destilasi

Hasil yang didapatkan dari proses destruksi didinginkan, setelah itu dilakukan pengenceran mengunkan aquadest sebanyak 100ml. dihomogenkan dan dinginkan, setelah itu diambil sampel sebanyak $5 \mathrm{ml}$ dan dimasukkan ke dalam labu destilasi. Ditambahkan 10ml larutn natrium hidrosida 30\% melalui dinding labu destilasi hingga terbentuk lapisam dibawah larutan asam. Dipasangkan labu destila dan dihubungkan dengan kondensor, setelah itu ujung kondensor dibenamkan dalam cairan penampung. Uap air dari cairan yang mendidih melalui kondensor da menuju erlenmeyer penampung. Pada erlenmeyer penampung ditambahkan 10ml larutan asam klorida $0,1 \mathrm{~N}$ yang sudah ditetesi degan indikator metih merah. Hasil dari proses destilasi dapat di cek menggunakan kertas lakmus, jika sudah tidak bersifat basa maka penyulingan dihentikan.

c. Tahap Titrasi

Hasil dari proses destilasi masuk kedalam tahap titrasi. Tabung erlemeyer digunakan sebaigai hasil destilasi yang berisi asam klorida $0,1 \mathrm{~N}$ dan ditambahkan indikator metil merah sebanyak 5 tetes. Kemudian dilakuakn titrasi dengan menggunkan larutan natrium hidroksida $0,1 \mathrm{~N}$. Akhir dari titrasi ditandai dengan perubahan warna larutan menjadi mrah mudah dan tidak hilang selama 30 detik.

\section{HASIL DAN PEMBAHASAN}

\section{Hasil Uji Aktivitas Antioksidan RSH-DPPH}

Hasil analisis varian menunjukkan bahwa semua perlakuan berbeda nyata. Peningkatan ini diduga dengan pengaruh waktu ekstraksi menyebabkan aktivitas antioksidan mengalami peningkatan. 
Tabel 1. Rerata Hasil Aktivitas Antioksidan Ekstrak Rambut Jagung

\begin{tabular}{|c|c|}
\hline Waktu Ekstraksi (Menit) & Antioksidan (\% \\
\hline P1: (20) & $65,44 \pm 0,32^{\mathrm{a}}$ \\
\hline P2: (30) & $67,19 \pm 0,78^{b}$ \\
\hline P3: (40) & $68,31 \pm 0,34^{\mathrm{c}}$ \\
\hline P4: (50) & $69,05 \pm 0,24^{\mathrm{d}}$ \\
\hline P5: (60) & $70,55 \pm 0,18^{\mathrm{e}}$ \\
\hline
\end{tabular}

Keterangan : angka yang di ikuti oleh huruf yang berebeda menunjukkan perbedaan yang nyata $(\mathrm{p}<0,05)$.

Hal ini diungkapkan oleh Wangensteen et al. (2004) yang menyatakan bahwa penggunaan pelarut yang bersifat polar akan diperoleh ekstrak polar yang menunjukan aktifitas antioksidan yang efektif. Hasil penelitian ini didukung oleh Haslina et al. (2019) yang memperoleh antioksidan tertinggi sebesar 50,41\% pada rambut jagung yang diekstrak dengan pelarut metanol $80 \%$ dengan perlakuan 60 menit dan suhu $40^{\circ} \mathrm{C}$ dengan ini ekstraksi menggunakan ultrasonik lebih efisien, waktu operasi lebih singkat dan laju perpindahan masa lebih cepat jika dibandingkan dengan ekstraksi konvensional menggunakan soxhlet. Hastuti, (2012) mengatakan bahwa perlakuan pemanasan menyebabkan rusaknya dinding sel dan subseluler dari tanaman herbal untuk membebaskan komponen aktif yang terkandung di dalamnya, dalam jumlah besar sehingga menghasilkan komponen yang dapat menangkap radikal bebas.

\section{Hasil Uji Total Fenol}

Analisis ragam menunjukkan bahwa waktu ekstraksi berpengaruh nyata $(\mathrm{p}<0,05)$ terhadap total fenol. Hasil analisa total fenol ekstrak rambut jagung dapat dilihat pada Tabel 2.

Tabel 2. Rerata Hasil Uji Total Fenol Ekstrak Rambut Jagung

\begin{tabular}{|ll|}
\hline Waktu Ekstraksi (Menit) & Total Fenol (mg.GAE/g) \\
\hline P1: $(20)$ & $1,48 \pm 0,10^{\mathrm{a}}$ \\
\hline P2: $(30)$ & $1,61 \pm 0,07^{\mathrm{b}}$ \\
\hline P3: $(40)$ & $1,71 \pm 0,07^{\mathrm{b}}$ \\
\hline P4: $(50)$ & $1,86 \pm 0,06^{\mathrm{c}}$ \\
\hline P5: $(60)$ & $1,98 \pm 0,09^{\mathrm{d}}$ \\
\hline
\end{tabular}

Keterangan : angka yang di ikuti oleh huruf yang berebeda menunjukkan perbedaan yang nyata $(\mathrm{p}<0,05)$.

Tabel 2 menunjukkan bahwa total fenol berkisar antara 1,48 - 1,98 mg.GAE/g terjadi perbedaan nyata terhadap rerata uji total fenol pada ekstrak rambut jagung. Hasil analisa varian menunjukan P1, P4, dan P5 beda nyata sedangkan P2 dan P3 tidak berbeda nyata. Peningkatan ini diduga pengaruh waktu ekstraksi sehingga menyebabkan total fenol mengalami peningkatan.

Peningkatan total fenol karena lama waktu ekstraksi dapat merusak dinding sel untuk mengeluarkan fenol dari jaringan tanaman, sehingga senyawa fenol yang terekstrak semakin tinggi jumlahnya. Selain faktor panas, tingginya kandungan fenolik karena ekstraksi yang dilakukan pada penelitian ini menggunakan metanol $70 \%$ serta menggunakan alat ultrasonik. 
Pada penelitian yang dilakukan oleh Haslina et al., (2019) ekstraksi meggunakan pelarut metanol dengan suhu $60^{\circ} \mathrm{C}$ selama 20 menit dengan rasio bahan : pelarut (1:4) menghasilkan total fenol paling tinggi sebesar 8216,89 Mg.QE/g jika dibandingkan dengan ekstraksi menggunakan pelarut ethanol, aseton, dan ethil asetat. Hal ini diungkapkan oleh Wangensteen et al. (2004) yang menyatakan bahwa penggunaan pelarut yang bersifat polar akan diperoleh ekstrak polar yang menunjukan kandungan fenol yang efektif.

Hal ini karena dengan suhu dan lamanya waktu ekstraksi, ia akan dapat melepaskan senyawa fenolik sel dinding atau senyawa fenolik terikat, sehingga menyebabkan lebih banyak senyawa fenol diekstraksi. Penggunaan suhu tinggi untuk ekstraksi dapat meningkatkan kelarutan fenol. Suhu tinggi dapat melepaskan sel-sel dinding fenol atau mengikat senyawa fenolik yang disebabkan kerusakan pada elemen sel, menyebabkan lebih banyak senyawa fenolik diekstraksi (Haslina et al., 2019).

\section{Hasil Uji Kandungan Flavonoid}

Analisis ragam menunjukkan bahwa waktu ekstraksi berpengaruh nyata $(\mathrm{p}<0,05)$ terhadap flavonoid. Hasil analisa flavonoid ekstrak rambut jagung dapat dilihat pada Tabel 3.

Tabel 3. Rerata Uji Kandungan Flavonoid Ekstrak Rambut Jagung

\begin{tabular}{|ll|}
\hline Waktu Ekstraksi (Menit) & Flavonoid (mg.QE/q) \\
\hline P1 : (20) & $2,05 \pm 0,07^{\mathrm{a}}$ \\
\hline P2: (30) & $2,25 \pm 0,03^{\mathrm{b}}$ \\
\hline P3 : (40) & $2,11 \pm 0,06^{\mathrm{a}}$ \\
\hline P4 : (50) & $2,31 \pm 0,05^{\mathrm{b}}$ \\
\hline P5 : (60) & $2,44 \pm 0,04^{\mathrm{c}}$ \\
\hline
\end{tabular}

$(\mathrm{p}<0,05)$

Keterangan : angka yang di ikuti oleh huruf yang berbeda menunjukkan perbedaan yang nyata

Tabel 3 menunjukkan bahwa kandungan flavonoid berkisar antara 20,05 2,44Mg.QE/ml mengalami peningkatan. Peningkatan ini diduga pengaruh waktu ekstraksi menyebabkan kandungan flavonoid mengalami peningkatan. Hasil analisis varian menunjukkan P1 sampai P2 berpengaruh nyata sedangkan pada P3 sampai P5 tidak berbeda nyata.

Kandungan flavonoid ini meningkat dari P1 sampai P5 dikarenakan bahwa meningkatnya suhu ekstraksi dapat meningkatkan kandungan flavonoid pada ekstrak rambut jagung. Menurut Haslina et al., (2019) dalam flavonoid terdapat senyawa fenol yang larut dalam pelarut polar bersama flavonoid yang menghasilkan nilai flavonoid yang tinggi dalam pelarut metanol. Pelarut yang memiliki sifat polar yang sama seperti flavonoid adalah metanol sehingga menghasilkan flavonoid yang tinggi. Flavonoid sangat sensitif terhadap panas karena tergabung dalam kelompok gugus hidroksil dan keton, dan terbungkus ikatan ganda tetapi flavonoid akan terdegradasi pada suhu di atas $100^{\circ} \mathrm{C}$.

Winata dan Yunianta., (2015) menyatakan bahwa semakin lama waktu ekstraksi, kuantitas bahan yang terekstrak juga semakin meningkat dikarenakan kesempatan untuk bersentuhan antara bahan dengan pelarut semakin besar sehingga hasilnya akan bertambah sampai titik jenuh larutan 


\section{Hasil Kadar Protein}

Analisis ragam menunjukkan bahwa waktu ekstraksi berbeda nyata $(\mathrm{p}<0,05)$ terhadap kadar protein. Hasil analisa kadar protein ekstrak rambut jagung dapat dilihat pada Tabel 4.

Tabel 4. Rerata Kadar Protein Ekstrak Rambut Jagung

\begin{tabular}{|ll|}
\hline Waktu Ekstraksi (Menit) & Protein $(\%)$ \\
\hline P1 : (20) & $0.63 \pm 0,01^{\mathrm{a}}$ \\
\hline P2 : (30) & $0,64 \pm 0,03^{\mathrm{b}}$ \\
\hline P3 : (40) & $0.61 \pm 0,01^{\mathrm{a}}$ \\
\hline P4 : (50) & $0.59 \pm 0,01^{\mathrm{b}}$ \\
\hline P5 : (60) & $0.58 \pm 0,00^{\mathrm{c}}$ \\
\hline
\end{tabular}

$(\mathrm{p}<0,05)$

Keterangan : angka yang di ikuti oleh huruf yang berbeda menunjukkan perbedaan yang nyata

Tabel 4 menunjukkan bahwa kadar protein berkisar antara 0,63-0,58\%, mengalami penurunan. P1 hingga P5 berbeda nyata. Kadar protein mengalami penurunan, hal diduga karena pada pengekstrakan rambut jagung mengalami peningkatan waktu yang disebabkan kandungan protein pada ekstrak rambut jagung berkurang karena adanya proses denaturasi protein. Damayanti (2004) menyatakan bahwa protein sangat peka terhadap panas dan akan mengalami perubahan struktur kimia (denaturasi) akibat adanya pemanasan. Winarno (1995), menambahkan pemanasan yang tinggi akan menyebabkan terjadinya degradasi pada molekul-molekul protein. Hasil degrasasi tersebut banyak menghasilkan turunan protein yang larut dalam air.

Tabel 4 menunjukkan kenaikan kadar protein pada perlakuan P1 sampai P2 namun pada P3 sampai P5 kadar protein mengalami penurunan karena disebabkan semakin lama waktu pengesktrakan maka kadar protein mengalami penurunan. Hal ini dikarenakan dengan semakin lama waktu ekstraksi akan menurunkan kadar protein pada ekstrak rambut jagung. Terjadinya penurunan kadar protein karena perlakuan pemanasan pada ekstraksi suhu dan menggunakan waktu yang lama menyebabkan terjadinya denaturasi protein. Hal ini sesuai dengan pernyataan Haslina et al., (2019) diduga semakin tinggi suhu dan lama ekstraksi, maka semakin rendah kandungan protein dari ekstrak rambut jagung serta semakin banyak protein larut dalam pelarut polar seiring meningkatnya suhu dan waktu ekstraksi. Kelarutan protein umumnya meningkat ketika suhu naik dari 0 ke $40^{\circ} \mathrm{C}$, dan semakin lama waktu pengekstrakan, kontak antara zat terlarut dan pelarut lebih lama maka akan banyak zat terlarut yang diambil.

\section{Hasil Kadar Vitamin C}

Analisis ragam menunjukkan bahwa waktu ekstraksi tidak berpengaruh nyata $(\mathrm{p}<0,05)$ terhadap kadar vitamin $\mathrm{C}$. Hasil analisa kadar vitamin $\mathrm{C}$ ekstrak rambut jagung dapat dilihat pada Tabel 5 . 
Tabel 5. Rerata Kadar Vitamin C Ekstrak Rambut Jagung

\begin{tabular}{|ll|}
\hline Waktu Ekstraksi (Menit) & Vitamin C (Mg100/ml) \\
\hline P1: $(20)$ & $57,15 \pm 0,63 \mathrm{a}$ \\
\hline P2: $(30)$ & $58,08 \pm 6,74 \mathrm{a}$ \\
\hline P3: $(40)$ & $57,71 \pm 1,37 \mathrm{a}$ \\
\hline P4: $(50)$ & $55,80 \pm 0,44 \mathrm{a}$ \\
\hline P5: $(60)$ & $53,98 \pm 0,48 \mathrm{a}$ \\
\hline
\end{tabular}

$(\mathrm{p}<0,05)$

Keterangan : angka yang di ikuti oleh huruf yang berbeda menunjukkan perbedaan yang nyata

Tabel 5. menunjukkan bahwa kadar vitamin C berkisar antara 57,71 - 53,98 Mg100/ml. P1 hingga P5 menunjukkan tidak berbeda nyata. Kadar vitamin C pada P1 dan P2 mengalami kenaikan, hal ini diduga karena waktu ekstraksi yang tepat, namun pada P3,P4, dan P5 mengalami penurunan, diduga penurunan ini disebabkan waktu pengekstrakan rambut jagung.

Tabel 5 menunjukkan pada P1 dan P2 mengalami peningkatan kadar vitamin C hal ini disebabkan waktu ekstraksi yang tidak merusak kadar vitamin. Namun pada P3 hingga P5 mengalami penurunan kadar vitamin $\mathrm{C}$, hal ini dikarenakan dengan semakin lama waktu ekstraksi akan menurunkan kadar vitamin $C$ pada ekstrak rambut jagung. Disebabkan vitamin $C$ sangat sensitif terhadap perlakuan pemanasan. Hal ini sesuai dengan pendapat Octaviani (2014) bahwa semakin tinggi suhu dan lama pemanasan menyebabkan degradasi vitaminC juga semakin besar. Oksidasi vitamin C (asam askorbat) akan mengubah asam askorbat menjadi asam L-dehidroaskorbat yang secara kimia sangat labil dan dapat mengalami perubahan lebih lanjut menjadi asam Ldiketogulonat yang tidak memiliki keaktifan vitamin $\mathrm{C}$ lagi.

Asam askorbat merupakan nutrisi penting sensitif terhadap panas, oksigen dan cahaya, hal ini dikarenakan vitamin $\mathrm{C}$ sangat rentan terhadap degradasi (Nindoa et al., 2007). Faktor lain yang dapat menyebabkan berkurangnya vitamin $\mathrm{C}$ dan menurut Rui et al. (2008), terjadinya reaksi antara vitamin C dengan peralatan yang digunakan pada pengolahan, misalnya bereaksi dengan kaca, logam, terutama tembaga dan besi dapat menurunkan kadar vitamin $\mathrm{C}$.

\section{Analisa Keputusan}

Analisa keputusan menggunakan uji de garmo (sarah-dejesus, 2014) terhadap aktivitas antioksidan, total fenolik, flavonoid, vitamin $\mathrm{C}$, dan protein. Adapun hasil rekapitulasi dapat dilihat pada Tabel 8.

Tabel 6. Total nilai penentuan perlakuan terbaik

\begin{tabular}{|c|c|}
\hline Perlakuan & Total Nilai \\
\hline P1 & 0.254 \\
\hline P2 & 0.485 \\
\hline P3 & 0.567 \\
\hline P4 & 0.567 \\
\hline P5 & 0.670 \\
\hline
\end{tabular}


Berdasarkan Tabel 6. Dapat dijelaskan bahwa keputusan perlakuan terbaik terhadap aktivitas antioksidan, total fenolik, flavonoid, vitamin $\mathrm{C}$, dan protein pada perlakuan pengesktrakan dengan suhu $60^{\circ} \mathrm{C}$ selama 60 menit. Hal ini dikarenakan pada perlakuan P5 memiliki jumlah nilai yang tinggi serta memiliki korelasi, diantaranya total fenol dan flavonoid yang tinggi dalam ekstrak rambut jagung menunjukkan aktivitas antioksidan yang tinggi. Ada hubungan antara kemampuan senyawa fenol sebagai antioksidan dan struktur kimianya. Konfigurasi dan kelompok hidroksil total adalah dasar yang secara signifikan mempengaruhi mekanisme aktivitasnya sebagai antioksidan. Ada korelasi

positif antara aktivitas antioksidan dan kandungan senyawa polifenol (Haslina et al., 2019). Hal ini membuktikan bahwa teknik ekstraksi ultrasonik dapat digunakan sebagai alternatif dalam mengekstrak senyawa antioksidan dari bahan alami. Keuntungan metode ultrasonik adalah untuk mempercepat proses ekstraksi dan memperbesar hasil ekstraksi.

\section{Kesimpulan}

\section{KESIMPULAN DAN SARAN}

Berdasarkan hasil penelitian pengaruh waktu ekstraksi menggunakan metode ultrasonik terhadap fitokimia ekstrak rambut jagung dapat disimpulkan bahwa :

1. Pengaruh waktu ekstraksi menggunakan metode ultrasonik terhadap fitokimia ekstrak rambut jagung berpengaruh nyata $(\mathrm{p}<0,05)$ terhadap uji aktivitas antioksidan, uji total flavonoid, fenol, kadar vitamin $\mathrm{C}$, namun tidak berbeda nyata pada uji kandungan protein

2. Pengaruh waktu ekstraksi rambut jagung terbaik adalah pada waktu 60 menit dengan hasil uji aktivitas antioksidan sebesar 70,55\%, uji kandungan flavonoid sebesar 2,44 mg.QE/g, uji total fenol sebesar 1,98 mg.GAE/g, kandungan vitamin c sebesar 53,98 Mg100/ml, dan kadar protein sebesar 0,58\%.

\section{Saran}

Berdasarkan penelitian yang telah dilakukan proses ekstraksi rambut jagung menggunakan metode ultrasonik dengan waktu 60 menit yang telah dilakukan, sebaiknya menggunakan waktu sampai titik optimum dan perlu dilakukan penalitian lebih lanjut. 


\section{DAFTAR PUSTAKA}

Ahmad, M.M., 2006, Anti Inflammatory Activity Of Nigella Sativa Linn(kalong, black seed), http://lailanurhayati.multiply.com/journal, diakses tanggal 13 Desember 2019

Akhilender. 2003. Dasar-Dasar Biokimia I. Erlangga, Jakarta.

Almatsier S. 2005. Prinsip Dasar Ilmu Gizi. Bandung: Alfabeta.

Aulina, Risqie. 2001. Gizi dan Pengolahan Pangan. Yogyakarta : Karya Nusa.

Association of Official Analytical Chemist (AOAC). 2005. Official Methods of Analysis of AOAC International Horwitz W. Ed ke-18. Publ AOAC International Maryland USA.

Barnes, Joanne, Linda A.A. dan Phillipson JD. 2007. Herbal Medicine: a Guide for Health Care Professionals. Third edition, Hal 191-192. Pharmaceutical Press. London.

Bi YG, Wang Z, Huang HL, Chen XW, Liu XM, Deng ST. Experimental research on single factor ultrasonic assisted extraction of polysaccharides from Gracilaria lemaneiformis. Advances in Engineering Research. 10: 85-89.

Chew, K. K., Ng, S., Y. Thoo, Y. Y., Khoo, M. Z., Wan, A. W. M and Ho, C. W, 2011. Effect of ethanol concentration, extraction time and extraction temperature on the recovery of phenolic compounds and antioxidant capacity of Centella asiatica extracts. International Food Research Journal. 18: 566-573.

Damayanti. 2004, Ilmu Teknologi Pangan Bahan Tambahan Makanan. Undip.

Duke, James A. 2017. Zea mays (Poaceae) Handbook of Phytochemical Constituents of GRAS Herbs and Other Economic Plants. https://phytochem.nal.usda.gov/phytochem/plants/show/2128?et=P. [Diakses 12 desember 2019].

Erukainure OL, Oke OV, Ajiboye AJ, Okafor OY. 2011. Nutritional qualities and phytochemical constituents of Clerodendrum volubile, a tropical nonconventional vegetable. International Food Research Journal 18(4):1393-1399.

Faesal. 2013. Pengolahan Limbah Tanaman Jagung Untuk Pakan Ternak Sapi Potong. Prosiding Seminar Nasional Inovasi Teknologi Pertanian. Badan Litbang Pertanian, Jakarta.

Fuadi A. 2012. Ultrasonik sebagai alat bantu ekstraksi oleoresin jahe. Jurnal Teknologi. 12(1):14-21.

Garcia J.L., Castro M.D.L., 2004. Ultrasound-assisted soxhhlet extraction : an expeditive approach for solid sample treatment, Application to the extraction of total fat from oleaginous seeds, Jornal of Chromatography A, Ed. 1034, pp.237242.

Guo J, Liu T, Han L, and Liu Y. 2009. The effect of corn silk on glycaemic metabolism. JournalNutrition and Metabolism Biomed Central,6:47.

Hala, A. 2011. Comparative Antioxidant Activity Study of Some Edible Plants Used Spices in Egypt. Journal of American Science. 7 (1): 230-239.

Harborne. 1987. Metode Fitokimia. Institut Teknologi Bandung Press Bandung.

Hasanudin, Khairunnisa, P. Hasyim, dan S. Mustafa. 2012. "Corn Silk (Stigma maydis) in Healthcare: A Phytochemical and Pharmalogical Review". Journal Molecules. 17: 9697-9715.

Hasttuti, Ningrum Dwi. 2012. Pembuatan Minuman Fungsional dari Maru dan Ekstrak Rosella (Hibiscus sabdariffa Linn). Jurnal Teknologi Pangan. Vol 3 no.1. 
Haslina dan Sri Untari. 2017. Pengaruh Waktu Ekstraksi dan Konsentrasi Ekstrak Rambut Jagung (Corn Silk) Terhadap pH, Total Fenol Dan Aktivitas Antibakteri. Fakultas Teknologi Hasil Pertanian. Universitas Semarang, Semarang.

Haslina, D. Praseptiangga, V. Priyo Bintoro dan Bambang P. 2019. The Optimization of Temperature and Length of Extraction of LocalCorn Silk Powder Using Response Surface Methodology.International Journal on Advanced ScienceEngineering Infromation Technology. Vol. 9, No. 2.

Haslina, D. Praseptiangga, V. Priyo Bintoro dan Bambang P. 2017. Chemical and Phytochemical Characteristics of Local Corn Silk Powder of Three Different Varieties. International Journal on Advanced ScienceEngineering Infromation Technology. Vol. 7, No. 5.

Lee, S. K and Kader, A. A. 2000.Preharvest and Postharvest Factors Influencing Vitamin C Content of Horticulture Crops. Postharvest Biology andTechnology Journal. 20 (3): 207-220.

Liu QM, Yang XM, Zhang L, Majetich G. 2010. Optimization of ultrasonic assisted extraction of chlorogenic acid from Folium eucommiae and evaluation of its antioxidant activity. Journal Medical Plants Res. 4(23):2503-2511.

Markham, K.R., 1988, Cara Mengidentifikasi Flavonoid, diterjemahkan oleh Kosasih Padmawinata, 15, Penerbit ITB, Bandung.

Margaretta, Sheila, S. D. Handayani, N. Indraswati dan H. Hindarso. 2011. Ekstraksi Senyawa Phenolic Pandanus amaryllifolius Roxb. Sebagai Antioksidan Alami. Vol. 10, No. 1, Hal: 21-30. Fakultas Teknik Kimia Universitas Katolik Widya Mandala, Surabaya.

Mittal R, Tavanandi HA, Mantri VA, Raghavarao KS. 2017. Ultrasound assisted methods for enhanced extraction of phycobiliproteins from marine macroalgae, Gelidium pusillum (Rhodophyta). Ultrasonics Sonochemistry. 38: 92-103.

Morais S. 2013. Functional Ingredients from Algae for Foods and Nutraceuticals. Porto (PT): Woodhead.

Nindoa, C.I., T. Sun., S.W. Wang., J. Tang and J.R. Powers. 2007. Evaluation of Drying Technologies For Retention of Physical Quality Andantioxid Ants in Asparagus (Asparagus officinalis, L.) Lebensm.-Wiss.u. Technol. 36 507-516 SwissSociety of Food Science andTechnology. Published by Elsevier Science Ltd. All rights reserved.

Nugroho, A. E., Suhardjono, D., Mulyono, S.a, dan Malik, A. 2013. Tptal Flavanoid and Fenolik Contents and in Vitro Antyhipertention Activity of Indonesia Cashew Leaves anacardiumoccidentale L. Fakultas Farmasi. UGM. Yogyakarta.

Nugroho Agung R. 2017. Pengaruh Ukuran Partikel Terhadap Karakteristik Ekstrak Rambut Jagung Hibrida DK 77 (Zea mays L). Fakultas Teknologi Pertanian, Universitas Semarang : Semarang,

Octaviani LF.2014. Pengaruh Berbagai Konsentrasi Gula terhadap Aktivitas Antioksidan dan Tingkat Penerimaan Sari Buah Buni (Antidesma bunius). [Skripsi].Semarang: Universitas Diponogoro.

Prayoga G. Fraksinasi. 2013. Uji Aktivitas Antioksidan dengan Metode DPPH dan Identifikasi Golongan Senyawa Kimia dari Ekstrak Teraktif Daun Sambang Darah (Excoecaria cochinchinensis Lour). Fakultas Farmasi Program Studi Sarjana Ekstensi Universitas Indonesia.2013.

Sharma, Om P. dan Bhat, Tej K. 2009. DPPH Antioxidant Assay Revisited. Food Chemistry (113): $1202-1205$. 
Simamora A. 2011. Flavonoid dalam apel dan aktivitas antioksidannya. [thesis]. Universitas Kristen Krida Wacana.

Wangensteen, H., Samuelsen and Maltrud, K. E. 2004. Antioxidant activity in extracts from coriander. International Journal Food Chem. 88: 293- 297.

Vanselow , M., KH, Lippermeire S, Hintze R. 2007. Determinioation of DPPH Radical Oxidation Caused by Methanolic Extracts of some Microalgal Species by Linear Regression Analysis of Spectrophotometric Measurements Sensor.

Winarno, F.G. 1995. Enzim Pangan. Penerbit PT. Gramedia Pustaka Utama. Jakarta. $113 \mathrm{Hlm}$.

Winarno, F.G. (2004). Kimia Pangan dan Gizi. Gramedia Pustaka Utama, Jakarta. 